\title{
MAPPING OF POTENTIAL SHOW CAVES IN THE RACHA LIMESTONE MASSIF (COUNTRY OF GEORGIA)
}

Lasha Asanidze

Ivane Javakhishvili Tbilisi State University, Vakhushti Bagrationi Institute of Geography, Tamarashvili street 6, Tbilisi,0177, Georgia.lasha.asanidze@tsu.ge

\section{Zaza Lezhava}

Ivane Javakhishvili Tbilisi State University, Vakhushti Bagrationi Institute of Geography, Tamarashvili street 6 , Tbilisi,0177, Georgia.zazalezhava@gmail.com

\section{Nino Chikhradze}

Ivane Javakhishvili Tbilisi State University, Vakhushti Bagrationi Institute of Geography, Tamarashvili street 6, Tbilisi, 0177, Georgia, Ilia State University, School of Natural Sciences and Engineering, Cholokashvili Ave 3/5, Tbilisi,0162, Georgia.nchikhradze@yahoo.com

\section{George Gaprindashvili}

Department of Geology, National Environmental Agency, Ministry of Environment Protection and Agriculture of Georgia, Agmashenebeli street 150, Tbilisi, 0112, Georgia. gaprindashvili.george@gmail.com

\section{Guranda Avkopashvili}

Ivane Javakhishvili Tbilisi State University, Elephter Andronikashvili Institute of Physics, Tamarashvili street 6, Tbilisi,0177, Georgia.gurandi19@gmail.com

\begin{abstract}
The Racha limestone massif is located in the eastern part of the karst zone of western Georgia. The massif is a typical example of Georgian mountain karst regions, where diverse surface and subsurface karst landforms are found. The main aim of this research is to present mapping of two potential show caves, and document speleological information from the Racha limestone massif. The morphological parameters and tectonic directions of the Muradi and Usholta Caves were mapped using the compass-clinometer and laser distance meter, to compile 3D models of the caves. To our knowledge these are the first 3D models of karst caves in Georgia.
\end{abstract}

\section{Introduction}

The country of Georgia is home to multiple, widespread limestone massifs with well-developed karst areas and their associated landscape features found throughout the country. The limestone massifs occupy more than 4,475 $\mathrm{km}^{2}$, or $6.4 \%$, of the entire territory of Georgia (Asanidze et al. 2013a; Asanidze et al. 2013b), and contain over 1,500 known caves (Asanidze et al. 2017a).

Given the variable tectonic influences, nature of the bedrock structure and hydrological complexity of the areas, the development of different types of karst features, including both hypogenic and epigenic caves, is not surprising (Tintilozov, 1976; Palmer, 2007; Ford and Williams, 2007).
In this paper we present new information on the Muradi and Usholta Cave systems focusing on speleogenic processes and secondary mineralogical deposits. The Muradi and Usholta caves are developed on the Racha limestone massif, the total area of which exceeds 590 $\mathrm{km}^{2}$ (Asanidze et al. 2017b; Asanidze et al., 2017c). Geographically, the Racha limestone massif is located in the Oni and Ambrolauri regions (western Georgia). The Racha limestone massif has the largest areal extent, but less relief compared to other karst regions in Georgia (Lezhava, 2015).

This work created the first 3D models of caves in Georgia, to our knowledge. The Muradi and Usholta Caves are important speleological objects and as potential show caves they can be used for the speleo-tourism purposes. The economic situation in this region is weak due to the lack of natural resources. The development of speleotourism is an important opportunity to improve the quality of life in this region (Debevec et al. 2012).

\section{Geological Settings of the Study Area}

The Racha limestone massif is a classic geomorphic region in the Caucasus in terms of the development of karst processes and landforms. The Bajocian porphyritic suite is the basis of the massif and Cretaceous carbonate rocks also influence the structure of the stratigraphy (Rakviashvili, 1985). Rocks from almost every part of the Early and Late Cretaceous exist in the region (Figure 1). 
The massif consists mainly of upper and lower Cretaceous and Paleogene limestones, which have an important influence on the origin and development of the surface and underground karst features and on the water table and its fluctuations (Rakviashvili, 1985). The prominence of karst processes in the region is high, due to the rapid movement of water along the structural weaknesses in the limestones. The fault dislocations provide locations for cave's inception and groundwater infiltration. Infiltration of surface water is rapid and there is almost no surface flow on the surface of the massif. Some small surface streams are mostly associated with the rainy and snowmelt periods.

\section{General Description of the Caves}

The Muradi Cave is located in the southwestern part of the Racha limestone massif in the Nakerala Range (Figure 1). The Nakerala Range comprises a small piece of the Racha limestone massif.

The Muradi Cave (elevation $1498 \mathrm{~m}$ a.s.l.) contains upper and lower levels. The lower level of the cave was discovered 15 years ago by a local resident and is about $171 \mathrm{~m}$ in length. In November 2014, the Mountaineers and Travelers Club accidentally found a new narrow corridor. After navigating the corridor, the club members explored a previously unknown, very interesting, upper level of the cave. A complex scientific study supervised by the lead author was subsequently conducted in the cave by speleological expeditions of the Vakhushti Bagrationi Institute of Geography of Tbilisi State University (TSU).

The Lower level of the Muradi Cave is dry and easy to pass through. In some parts of the lower level limestone rocks are collapsed from the ceiling.

Secondary calcite deposits are rare in the lower section of the cave. The upper level of the cave is connected to the lower level via 10 meters of vertical passage and totally is 489 meters in length. The total length of Muradi Cave is $660 \mathrm{~m}$. The upper level, in contrast to the lower level, contains almost all types and subtypes of calcite deposits which are recorded in the caves of the Caucasus region (Tintilozov, 1976).

The Usholta Cave is located in the eastern part of the Racha limestone massif at an elevation of $1817 \mathrm{~m}$ a.s.l.

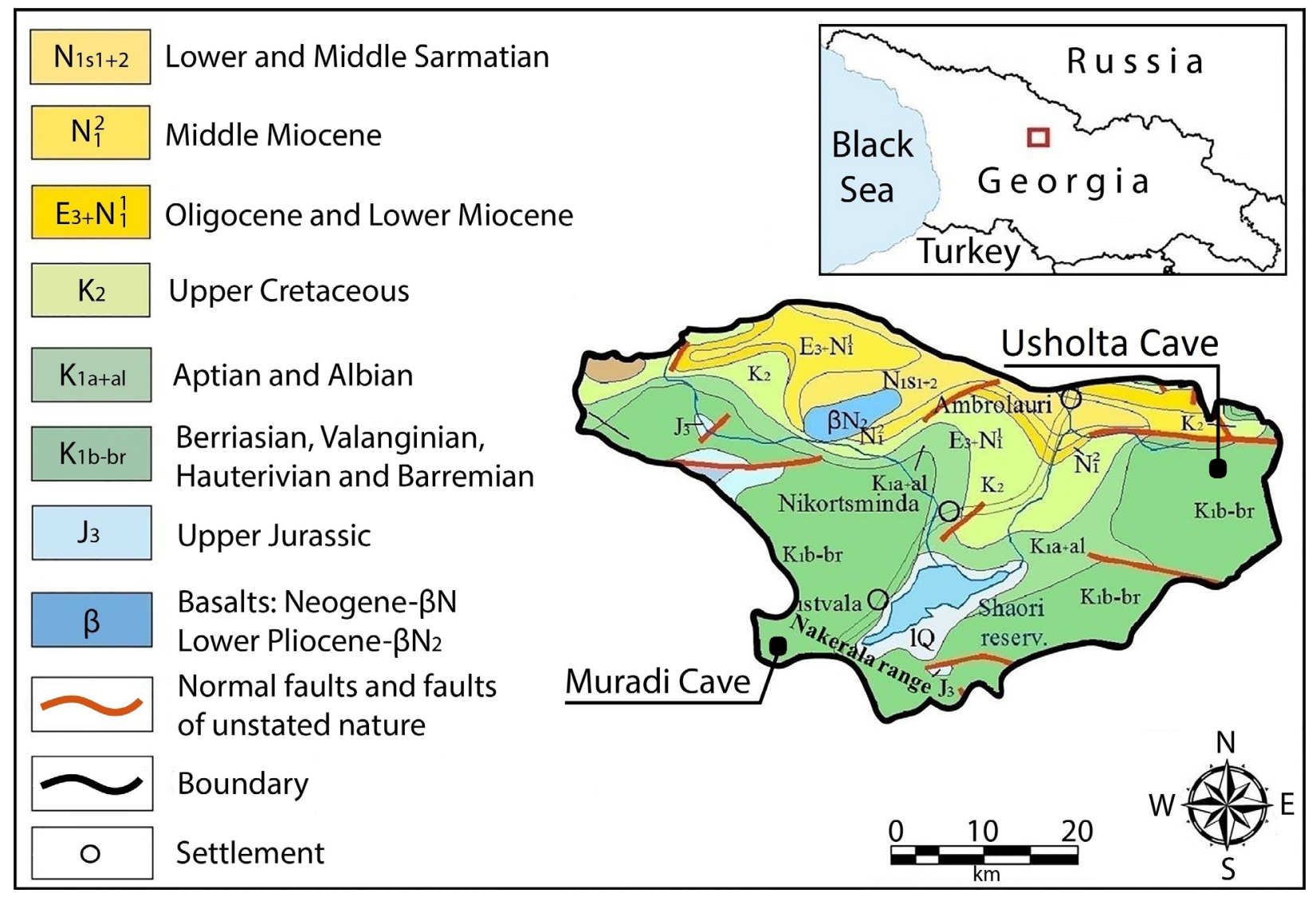

Figure 1. Geological map of the Racha limestone massif (after Gujabidze, 2003). Location of the Muradi and Usholta Cave systems. 
(Figure 1). The Usholta Cave was discovered in the 1960 s, but the cave was only partially explored. Only a line map of the cave was produced at that time. The cave has only one level with two main branches. Some parts of the cave floor are covered with the limestone rocks fallen from the ceiling, which makes it difficult to traverse these areas. A complex scientific study supervised by the lead author was subsequently conducted in the cave by speleological expeditions of the Vakhushti Bagrationi Institute of Geography of Tbilisi State University (TSU).

\section{Methodology}

The basic methods applied for studying classical karst regions and underground cavities have been used during this study. For the first step, at the entrances of the Muradi and Usholta Caves, we took several points using GPS 60cs, by which the coordinates and altitudes of the caves were defined. The morphological parameters and tectonic directions of the Muradi and Usholta Caves were measured using a compass-clinometer and a laser distance meter (in the Muradi Cave we took 40 points, and in the Usholta Cave we took 50 points at various distances between cave walls, ceilings and floors), from which we compiled the $3 \mathrm{D}$ models of the caves. Air and water temperatures $\left({ }^{\circ} \mathrm{C}\right)$ were measured in different places within the caves using an Onset HOBO Pro V2 Data Logger and the Enviro Safe portable thermometer.

\section{Results and Discussion}

\section{Cave survey, mapping and data processing}

The goals of this research included the detailed survey and mapping of these caves and collection of information from speleological point of view for speleo-tourism development in the Racha limestone massif. The goals address the questions: 1) are these caves of sufficient scientific value to necessitate careful study, protection and preservation, and 2) to provide information to enable an economic evaluation of these caves potentials to be developed into viable speleo-tourist attractions.

While rough maps from traditional survey methods can be suitable for general navigation through a cave, for some applications, such as scientific research and environmental assessment, greater detail and resolution are required (Zlot and Bosse, 2014). At the same time, the limited accessibility and light conditions make mapping of cave morphology very difficult (Gallay et al. 2015).

During several expeditions in the Racha limestone massif, the caves were surveyed using a compass, clinometer, and laser distance meter. The survey of the Muradi Cave shows that it has one main passage (lower and upper passages) with three shorter branches - one is located in the lower passage, and two of them are located in the upper passage. The 171-meter long horizontal section of the main, lower cave level connects with the upper level through a $10-\mathrm{m}$ vertical passage. Near the end of the upper level of the cave there are four karst shafts $11,42,35$, and $37 \mathrm{~m}$ deep respectively, which are connected to each other through the narrow holes. The cold air mass movements are palpable in the karst shafts section. In the authors' opinion, this air movement is probably related to unobserved holes existing in the cave. In the right corner of the passage (azimuth $95^{\circ}$ ), a wide $(5 \mathrm{~m})$ and long $(34 \mathrm{~m})$ tunnel-shaped passage is formed in the Urgonian limestones. By the Compass cave survey software and ArcGIS the 3D map of the cave was created within the context of the landscape (Figure 2).

No permanent streams enter the Muradi Cave and no traces of modern, ephemeral stream actions are evident in the upper passage. On the other hand, the influence of infiltration and condensate waters is obvious. Intense movement of cold air $\left(5^{\circ} \mathrm{C}\right)$ observed in the terminal section of the cave is evidence of a possible extension of the cave. Several times in 2015 and 2016, the air temperature was measured in the two sections of the cave, one - at the entrance (slightly above $7^{\circ} \mathrm{C}$ ), and the second - at the end of the cave, near where the speleothems were formed in a pool of water. Near this pool, the water temperature was also measured to be $7^{\circ} \mathrm{C}$.

The Usholta Cave is developed on a single, horizontal level with two main branches. The second, an $800 \mathrm{~m}$ long, previously unknown branch, was discovered in 2015 during a speleo-geomorphological exploration expedition led by the lead author. It is planned to investigate the mentioned branch, but it is related to certain difficulties, since the branch is periodically being narrowed, very much that makes it harder to move into the depths.

The cave, which has two main branches. The total length of the cave is $2 \mathrm{~km}$. Based on the survey data, Compass cave survey software and ArcGIS was used to create a 3D map of the cave within the context of the landscape (Figure 3).

Episodic and seasonal speleo climate observations were conducted several times in the Usholta Cave between 2014 and 2016. No substantial changes in the air and water temperatures were observed at specific monitored locations. Water levels in the stream passing through the cave were almost constant and did not vary significantly. The air temperature was measured in the two sections of the cave, one - near the entrance $\left(10^{\circ} \mathrm{C}\right)$, and the second - at the end of the cave $\left(6.8^{\circ} \mathrm{C}\right)$. Also, the water temperature was measured in the two different places of the cave, one near the entrance $\left(6.4^{\circ} \mathrm{C}\right)$, and the second at the end of the cave $\left(4.8^{\circ} \mathrm{C}\right)$. In the opinion of the authors, significant difference of water and air temperature is caused by the following factors, including as follows: 1 . 


\section{MURADI CAVE}

\section{Pool calcite speleothems}

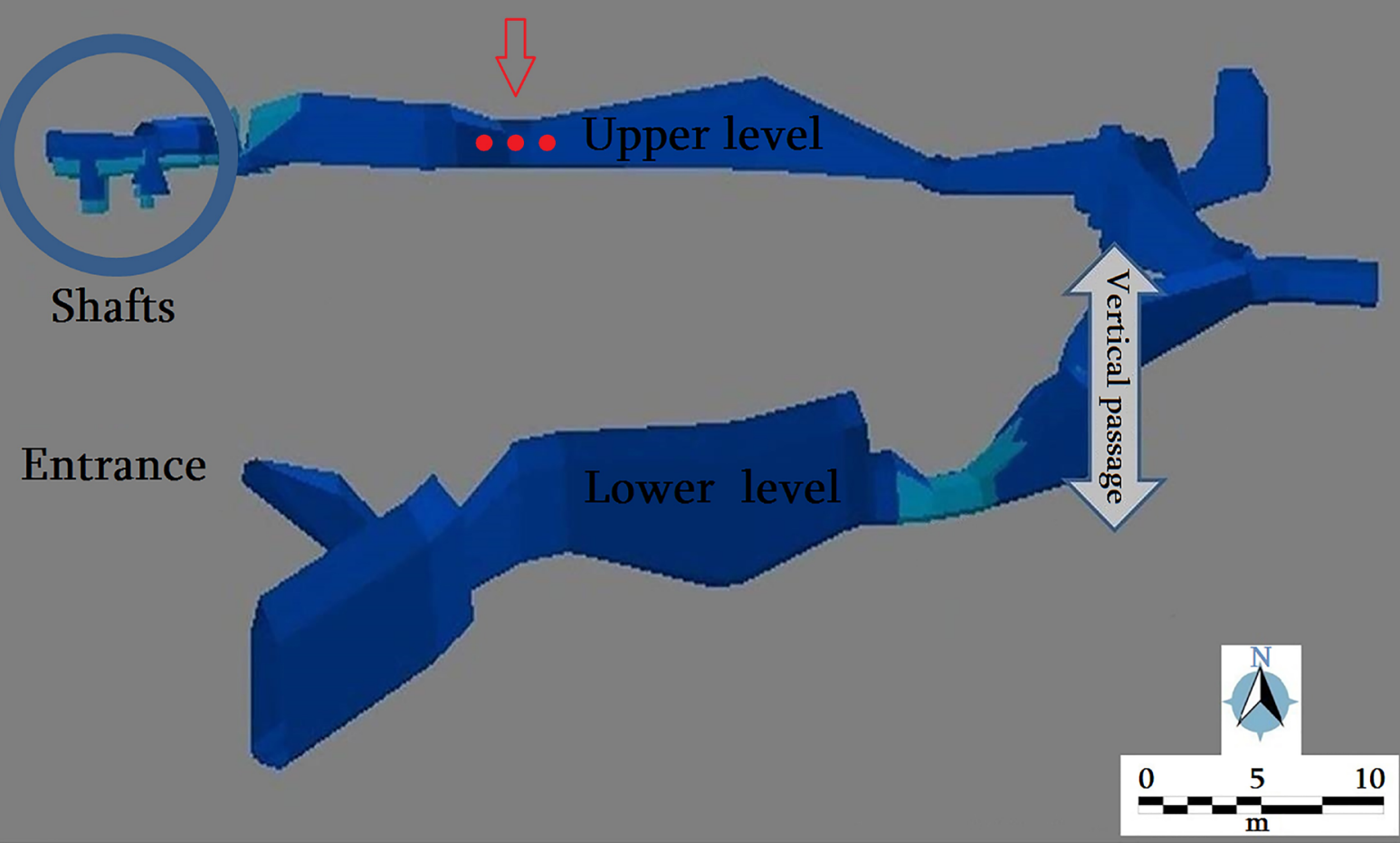

Figure 2. The Compass-generated 3D model of the Muradi Cave (by Lasha Asanidze).

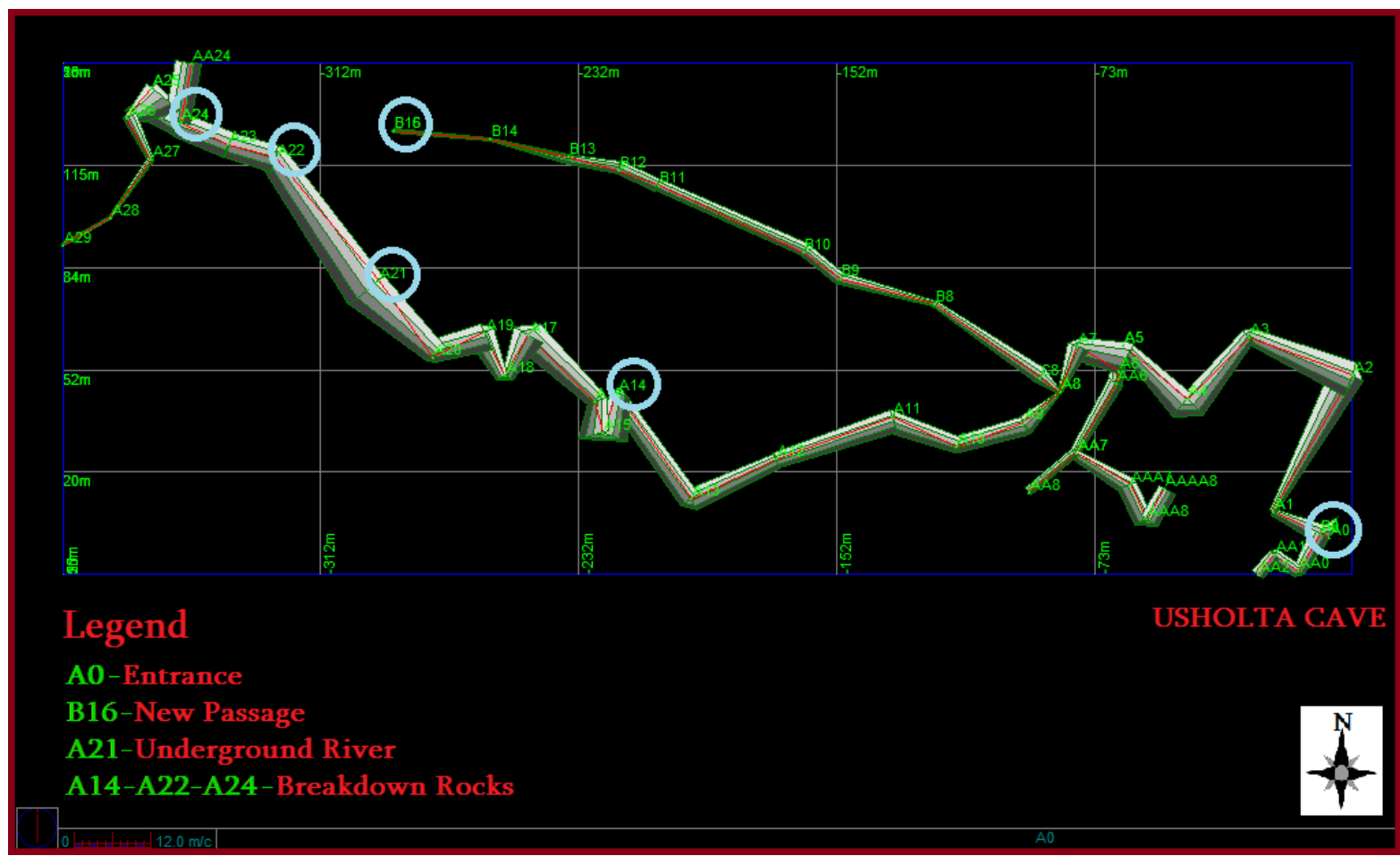

Figure 3. The Compass-generated 3D model of the Usholta Cave (by Lasha Asanidze). 
The morphology of the cave; 2 . Intensive inflow of cold water in the cave; 3 . Hypsometric location of the cave, etc.

\section{Secondary mineral deposits (poolspeleothems)}

The Muradi Cave, which may become a very popular speleo object in this region, is a very rich in calcite speleothems. The cave contains almost all types and subtypes of speleothems recorded in the caves of the Caucasus region (Lezhava, 2015; Tintilozov, 1976). Beautiful examples of spherical formations (pool speleothems), formed by calcite mineral aggregates, give the cave particular uniqueness and there is no known analog in caves in the whole Caucasus region (Figure $4,5)$. They are mostly subaqueous, lithified calcite balls of different sizes (the smallest is $16 \mathrm{~cm}$ and the largest is $180 \mathrm{~cm}$ in circumference) at one level in a shallow pool in the Muradi Cave in the upper level. They seem to have been formed at the same level in the water, perhaps as formations similar to phreatic overgrowth from supersaturated waters existing at higher water levels during times of tectonic change, flooding, or base level shifts and thus indicating a period of higher water table and stability in between tectonic shifts (Bieniok et al.
2011; Merino et al. 2014; Jacek, 2015). X-ray diffraction (XRD) analysis confirmed that these are $100 \%$ calcite deposits (Asanidze et al. 2017d; Asanidze et al. 2017e).

One of the interesting formations found in the Muradi Cave is a moonmilk, which is not very common in the caves of the Caucasus region (Tintilozov, 1976). This formation is mostly found in the wet passages and occurs in pools of water. The moonmilk is actively formed under the aggressive influence of condensate waters. The aggressive waters, by dissolving the limestone walls, lead to the formation of the moonmilk (Hill and Forti, 1997; Merino et al. 2014; Borsato et al. 2000) and, often, infiltration waters also participate in this process. A study by Geze (1965) suggests that microorganisms play an active role in their formation (biochemical weathering) as well, but more work is needed in the Muradi Cave to better determine that possibility.

However, other authors, such as Shumenko and Olimpiev (1977), did not find microorganisms in the moonmilk they studied. It appears, then, that microorganisms are possible, but not essential factor in the formation of moonmilk (Hill and Forti, 1997).

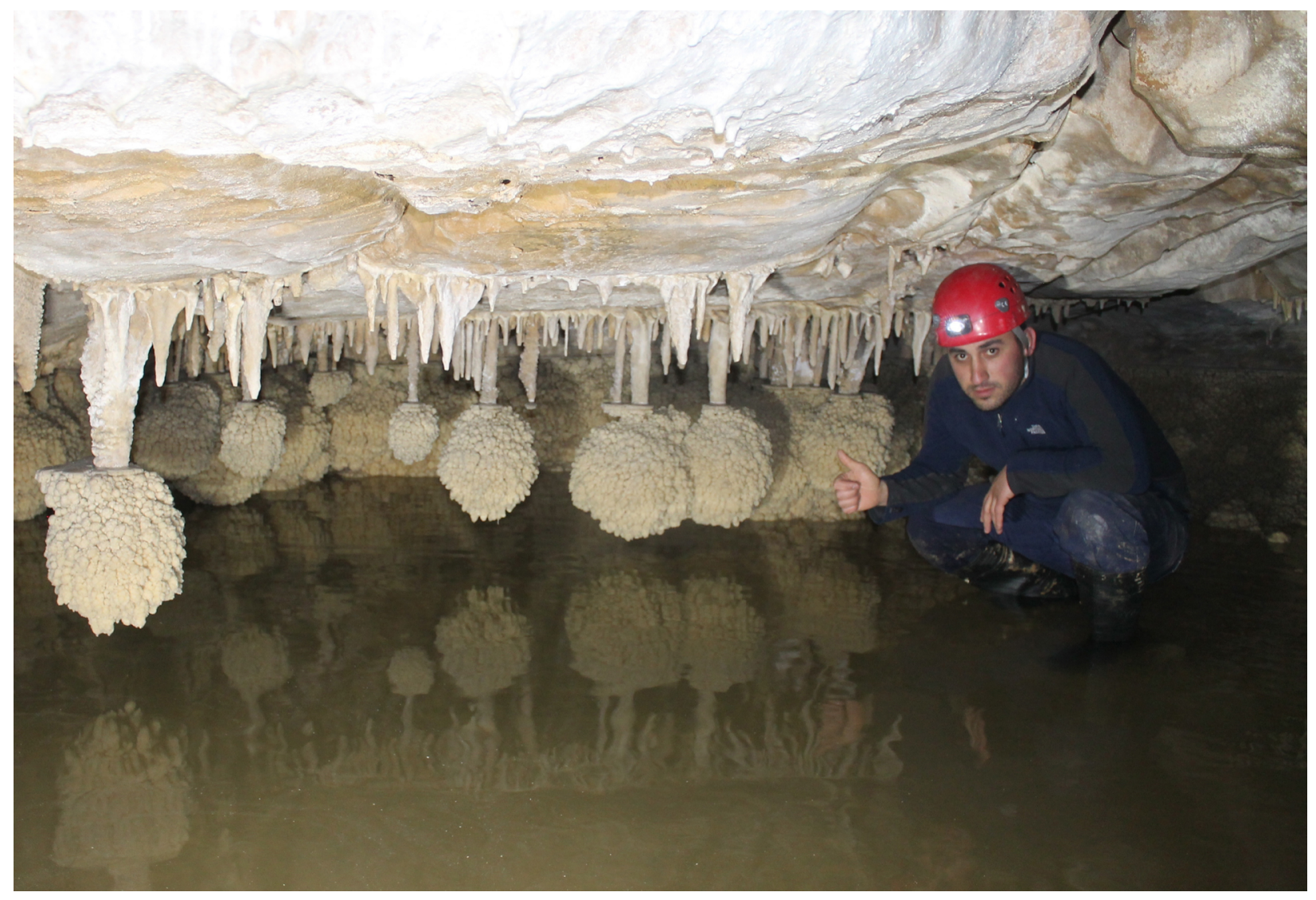

Figure 4. The spherical examples of pool calcite speleothems, which could be formed from water level fluctuations over time (photo by George Lominadze). 


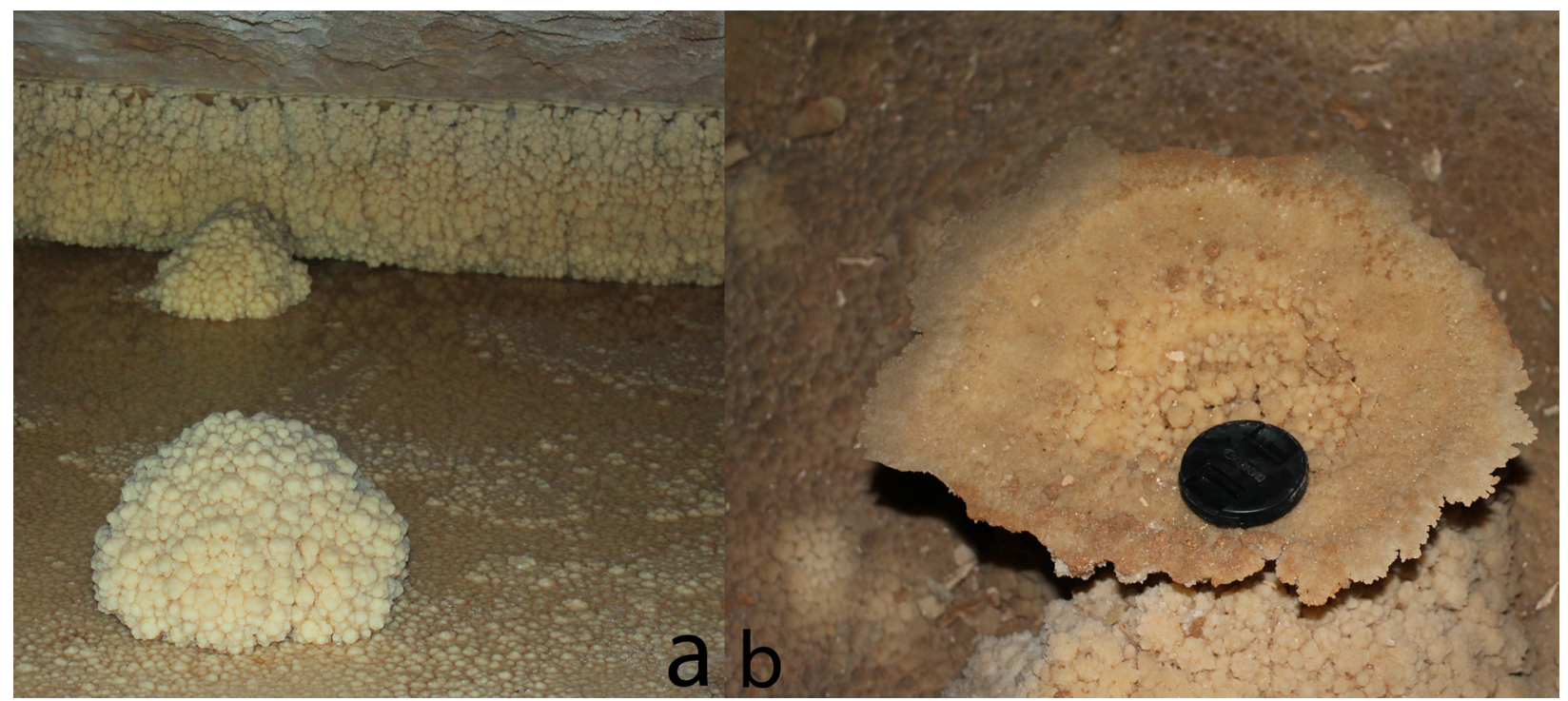

Figure 5. a) The pool calcite speleothems deposited subaqueously in cave pools at multiple places of the Muradi Cave. b) Cave cup developed in the shallow pool of the Usholta Cave (photos by Lasha Asanidze).

In contrast to the Muradi Cave, calcite speleothems are almost completely absent in the Usholta Cave. Based on the speleo-geomorphological and field studies we note that the ceiling and the walls of the Usholta Cave are devoid of crack chain and that limits the infiltration of the water into the cave. We interpret the absence of the crack chains to be one of the reasons that calcite formations did not develop in the Usholta Cave. The opposite condition is present in the Muradi Cave where the intensive fracturing contributes to the development of the unique calcite forms, which are developed near the clefts.

\section{Conclusions}

This research effort has created, for the first time in Georgia, electronic databases in Geographic Information Systems (GIS) for the Racha limestone massif. These data bases include: Climatic characteristics of the caves; Morphometric parameters; Speleological descriptions and more other information. This information is regularly updated and it can be provided for the cave research. This research effort also created the first 3D models of the caves in Georgia. Muradi and Usholta Caves are important speleological objects and they potentially can be used for the speleo-tourism purposes. Speleological surveys of caves and detailed 3D models will be useful background information for any future speleo-tourism development.

\section{Acknowledgements}

We are deeply grateful to Dr. Jason Polk (Western Kentucky University, Dept. of Geography and Geology) for support to measurement the mineralogical composition of some speleothems from the Muradi Cave. We also would like to thank the Shota Rustaveli National Science Foundation for the research funding within the Doctoral Programs Grant № DO/80/9-280/14.

\section{References}

Asanidze L, Tsikarishvili K, Bolashvili N. 2013a. Cave Tourism Potential in Georgia. The 2nd International Symposium on Kaz Mountains (Mount Ida) and Edremit. Edremit- Turkey, Proceedings \& Abstracts. p. 243-247.

Asanidze L, Tsikarishvili K, Bolashvili N. 2013 b. Speleology of Georgia. 16th international congress of speleology, Brno, Czech Republic. volume 1. p. 29-32.

Asanidze L, Chikhradze N, Lezhava Z, Tsikarishvili K, Polk J, Chartolani G. 2017a. Sedimentological Study of Caves in the Zemo Imereti Plateau, Georgia, Caucasus Region. Open Journal of Geology. Vol, 7. p. 465-477.

Asanidze L, Avkopashvili G, Tsikarishvili K, Lezhava Z, Chikhradze N, Avkopashvili M, Samkharadze Z, Chartolani G, 2017b. Geoecological Monitoring of Karst Water in Georgia, Caucasus (Case Study of Racha Limestone Massif). Open Journal of Geology. Vol, 7. p. 822-829. 
Asanidze L, Lezhava Z, chikhradze n. 2017c. Speleological Investigation of the Largest Limestone Massif in Georgia (Caucasus). Open Journal of Geology. Vol, 7. p. 1530-1537.

Asanidze L, Lezhava Z, Tsikarishvili K, Chikhradze N, Polk J. 2017d. Karst morphological processes and evolution of the limestone massif of Georgia from depositional, sedimentary, and structural investigations in Muradi Cave. Proceedings of 17th international congress of speleology, at Sydney, Australia.

Asanidze L, Chikhradze N, Lezhava Z, Tsikarishvili K, Polk J, Lominadze G, Bolashvili N. 2017e. Complex Speleogenetic Processes and Mineral Deposition in the Caucasus Region of Georgia. Journal of Environmental Biology. 38, p. 11071113.

Bieniok A, Zagler G, Brendel U, Neubauer F. 2011. Speleothems in the dry cave parts of the Gamslöcher-Kolowrat Cave, Untersberg near Salzburg (Austria). International Journal of Speleology, 40 (2), 117-124.

Borsato A, Frisia S, Jones B, Van der borg K, 2000. Calcite Moonmilk: Crystal Morphology and Environment of Formation in Caves in the Italian Alps. Journal of Sedimentary Research. Vol. 70, No. 1179-1190.

Debevec B, Knez M, Kranjc A, Pahor M, Prelovsek M, Semeja A, Slabe T. 2012. Preliminary study for the adaptation of the Heaven's Cave, for tourist purposes (Phong Nha-Ke Bang National Park, Vietnam). Acta Carsologica 41/1, 115-127.

Ford DC, Williams PW. 2007. Karst geomorphology and hidrology. Wiley, pp. 576, United Kingdom.

Gallay M, Kaňuk J, Hochmuth Z, Meneely Jd, Hofierka J, Sedlák V. 2015. Large-scale and high- resolution 3-D cave mapping by terrestrial laser scanning: a case study of the Domica Cave, Slovakia. International Journal of Speleology. 44 (3). 277 291.

Geze B. 1965. La Spéleologie Scietifique. Paris, 190.

Gudjabidze GE. 2003. Geological map of Georgia, Scale 1:500 000. (Editor: Gamkrelidze et al.). Georgian State Department of Geology and National Oil Company Saqnavtobi. Tbilisi, Georgia.

Hill CA, Forti P. 1997. Cave Minerals of the world (2nd ed). National Speleological Society. Huntsville, USA.

Jacek S. 2015. Cave development in an uplifting foldand-thrust belt: case study of the Tatra Mountains, Poland. International Journal of Speleology 44 (3), 341-359.

Lezhava Z. 2015. The Karst of Zemo Imereti plateau and its surrounding areas. Publishing House Universali (in Georgian). Tbilisi, Georgia.
Merino A, Gines J, Tuccimei P, Soligo M, Fornos J. 2014. Speleothems in Cova des Pas de Vallgornera: their distribution and characteristics within an extensive coastal cave from the eogenetic karst of southern Mallorca (Western Mediterranean). International Journal of Speleology, 43 (2), 125-142.

Palmer AN. 2007. Cave geology. Dayton, OH. Cave Books.

Rakviashvili K. 1985.On karst of the elevated Dzirula massif and Shaori tektonical block. Caves of Georgia. The collection, Issue 10. (in Russian), Tbilisi, 55-62.

Shumenko SI, Olimpiev IV. 1997. Rock milk from caves in the Crimea and Abhazia: Lithology and Mineral Res., v. 12, no. 12 (in Russian), 240-243.

Tintilozov ZK. 1976. Karst caves of Georgia (morphological analysis). (in Russian). Tbilisi, Georgia.

Zlot R, Bosse M. 2014. Three-dimensional mobile mapping of caves. Journal of Cave and Karst Studies, v. 76, no. 3, p. 191-206. DOI: 10.4311/2012EX0287. 
